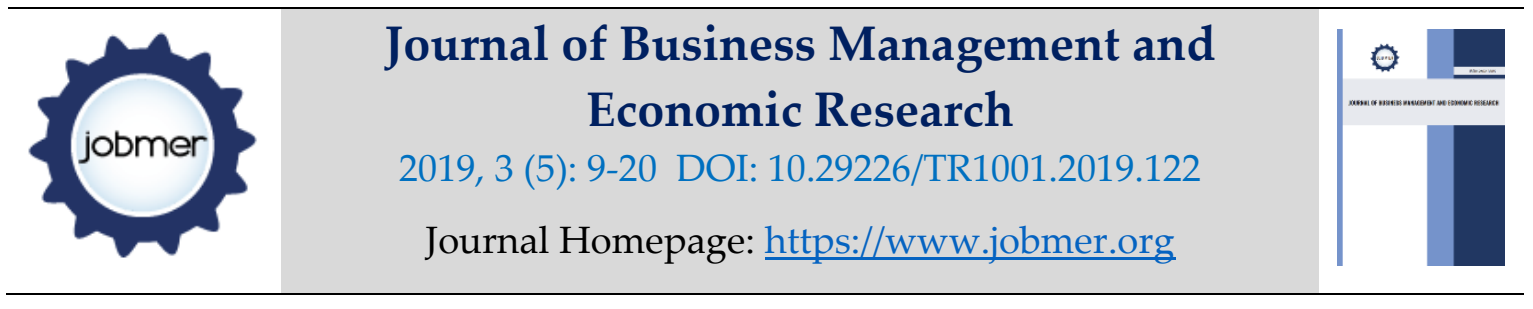

\title{
The Effect of Customer Relationship Management on the Satisfaction to Build Customers' Loyalty (Study Case of Go-Jek's Transportation Service Users)
}

\section{Deby Carolina}

Udayana University, Bali, Indonesia debylin31@gmail.com

\section{Ni Nyoman Kerti Yasa}

Udayana University, Bali, Indonesia

kertiyasa@unud.ac.id

\begin{abstract}
This study aims at explaining the effect of the CRM (continuity marketing, one to one marketing, and partnering programs) on customers' satisfaction and loyalty. This research was conducted on Go-Jek transportation service users in Denpasar city with a total sample of 100 respondents determined based on non probability sampling method namely purposive sampling. The application of CRM is measured by using questionnaires. The analytical tool used in this study is descriptive statistical test and inferential statistical test in the form of path analysis test. The results of the study show that continuity of marketing, one to one marketing, and partnering programs have a positive and significant effect on customers' satisfaction. One to one marketing is the variable that most influences customers' satisfaction. Customers' satisfaction also has a positive and significant influence on customers loyalty, so it can be concluded that forming customer loyalty can be done by improving the customers' satisfaction.
\end{abstract}

Keywords : Customer Relationship Management (CRM), Customer Satisfaction, Customer Loyalty

\section{Introduction}

The rapid development of business and technology has made competition even tighter so that businesses need to innovate to provide the best service for customers, ranging from the availability of diverse services, competitive pricing, to the application of distribution which in 
the past days were in conventional systems but now to online systems. One of them that is developing in Indonesia is the application of an online system on wheels.

Ojek is a mode of public transportation in the form of a motorcycle. Before the existence of an online system, motorcycle taxis can only be obtained at certain points of a region. Over time, motorcycle taxi bookings are made online through a special application via mobile that connects the driver and the customer. This phenomenon began to shift the culture of society, especially in the city of Denpasar, related to the lifestyle of the people through easy access to transportation modes.

Based on the results of a survey of users of online transportation services, it can be seen that online transportation is more attractive for public because it is safe, inexpensive and faster instead of conventional transportation mode. The survey also showed that Go-Jek is in the highest rating for the category of customer choice online transportation, followed by Grab, Uber, and My Bluebird (ylki.or.id). But, these reasons have not been able to direct the public to think positively about online transportation services. Based on the results of the pre-survey of 15 respondents who are users of Go-Jek transportation services among students, it appears that there are still various complaints that arise in online transportation services such as the drivers are unfriendly, the lack of drivers' ability to apply technology, the availability of supporting facilities who have not been able to meet customer needs, and driving skills that are considered poor.

Complaints are very vulnerable to creating negative perceptions of online transportation services, so it is important for businessmen to build good relationships among customers. The variable of customer relationship management (CRM) is one of the strategic approaches in building good relationships with customers (Kotler and Keller, 2012). Sheth et al. (2015) divide the CRM into three types of programs, namely continuity marketing, one to one marketing and partnering programs that aim to improve customers' satisfaction which will continually create customer loyalty. Customers' satisfaction must be fostered from time to time to build loyalty in the minds of customers (Setyaleksana et al., 2017). Kotler and Keller (2012) define customer satisfaction as one of the factors that determine customer's loyalty. In other words, customers will not be loyal to a product before they feel satisfied with the product (Koduah and Farley, 2016).

Even though the Go-Jek has implemented the continuity marketing, one to one marketing and partnering program through the features in the application, Go-Jek has not been able to obtain 
maximum results from the implementation of the program. In other words, even though the CRM program has been done, there are still some customers who are not satisfied with the services provided so that they are reluctant to be loyal to the Go-Jek transportation service.

The empirical studies of similar phenomena have been done before, some studies have shown significant results, but some have shown conflicting results. One research conducted by Adha and Bramantory (2013), Bhaskara et al. (2014), Maidi and Suwitho (2014), Sutrisno (2015), and Supar and Suasana (2017) stated that CRM has a positive and significant effect on customers' satisfaction. These results contradict Iriandini's research et al. (2015) which states that CRM does not significantly influence customers' satisfaction. Contradictory results were also found in several studies regarding the effect of customers' satisfaction on customer loyalty. Arokiasamy (2013), Mardikawati and Farida (2013), Ariff et al. (2013), and Sutrisno (2015) stated that customers' satisfaction has a positive and significant effect on customer loyalty. However, Oktariana et al. (2012), and Iriandini et al. (2015) stated the opposite which is customer satisfaction does not significantly influence the customer loyalty.

Based on the problems faced by Go-Jek transportation services in Denpasar and the inconsistency of the results of previous research, this study was prepared with the aim of explaining the effects of continuity of marketing, one to one marketing and partnering programs on customers' satisfaction with Go-Jek transportation service users and to explain the effect of customers' satisfaction on customer loyalty to Go-Jek transportation service users.

\section{Theoretical Review and Research Hypothesis}

CRM is a group of corporate information systems, one of which is through technology management to create customer relationships and collect, store and analyze customer data to provide a comprehensive view of their customers (Khodakarami and Chan, 2014; Paliouras and Sirakas, 2017).

Sheth (2015) states that there are three types of programs in building CRM, namely continuity of marketing, one to one marketing, and partnering programs. Continuity marketing is a marketing program to sustain and improve customer value continuously by applying 1) membership card; 2) reward points; 3) discounts; 4) vouchers that are useful in building extensive customer databases to enable companies to truly understand customers and anticipate their needs (Mokodongan, 2010; Oesman, 2010; Indah, 2013; Sheth et al., 2015; Felix et al., 2016; Supar, 2017; Sirait, 2018). One to one marketing is a program carried out individually aimed at meeting the unique needs of customers. The application of this program can be seen 
from 1) employee friendliness and politeness; 2) employee speed and skills; 3) complaint handling by employees; 4) giving greeting cards to employees; 5) greetings by employees to customers (Indah, 2013). Partnering program (partnership program) is a cooperative relationship between marketers and other companies to serve customer needs. The partnership program implemented by the company will be able to create relationships with customers, grow and maintain relationships with customers both short and long term (Ardiyhanto, 2011). Oesman (2010) states that partnerships are the most dominant strategy in an effort to build customer satisfaction. Kotler and Armstrong (2014) state that most companies have networks that are highly dependent on partnerships with other companies. Based on a brief description of the three programs, in broad outline it can be understood that CRM programs foster short-term relationships, namely improving customer satisfaction and a long-term relationship that is forming customer loyalty.

Customer satisfaction is a feeling of one's pleasure or disappointment which appears after comparing the products' performance that is thought of the expected performance (Kotler and Keller, 2012: 177). Customer satisfaction is measured through three indicators, including: 1) general or overall satisfaction; 2) price suitability, namely the level of conformity between actual performance and price; 3) comparison with ideal situations, namely product performance compared to ideal products according to customer perceptions (Saputra et al., 2015). Companies with satisfied customers have a high chance to turn them into loyal customers (Mohsan, 2011). Customer loyalty is a relationship between customer engagement with the brand of a product or service, or other entities based on favorable attitudes and behavioral responses such as repeat purchases (Zakaria et al. 2013). Griffin (2005: 31) states that customers can be said to be loyal if they meet several indicators including: 1) making repeated purchases regularly; 2) buy another product line or service in the same business entity; 3) referring to others.

A description of the relationships between variables in this study can be described visually through the conceptual framework presented at Picture 1. 


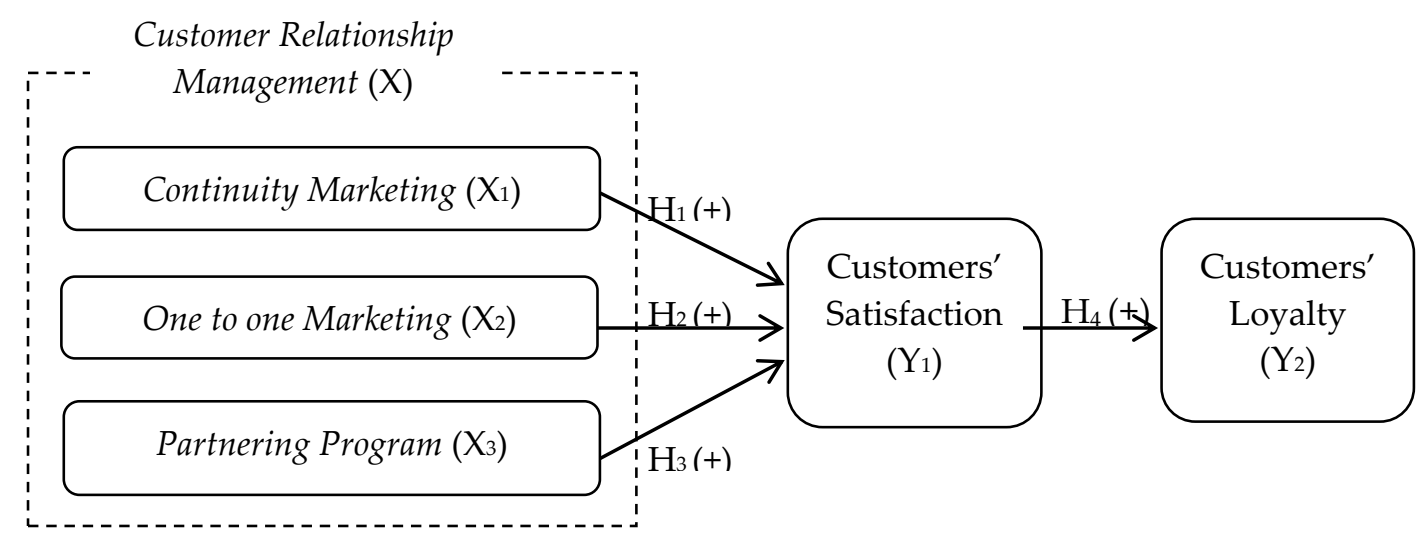

Figure 1. The Conceptual Framework

Based on the conceptual framework, the hypothesis can be formulated as follows.

$\mathbf{H}_{1} \quad$ : Continuity marketing has a positive and significant effect on customer satisfaction.

$\mathbf{H}_{2}$ : One to one marketing has a positive and significant effect on customer satisfaction.

$\mathrm{H}_{3} \quad$ :

Partnering program has a positive and significant effect on customer satisfaction.

Customers' satisfaction has a positive and significant effect on customer $\mathbf{H}_{4}$ : loyalty.

\section{Research Methods}

This research is a type of quantitative research because its findings are achieved by using statistical procedures. This study is associative because it aims to determine the effect of independent variables on the dependent variable. This research was conducted in Denpasar city.

There are two types of variables in this study, namely 1) independent variables: continuity marketing $\left(X_{1}\right)$, one to one marketing $\left(X_{2}\right)$, and partnering $\left(X_{3}\right)$; and 2$)$ dependent variable: customer satisfaction $\left(\mathrm{Y}_{1}\right)$ and customer loyalty $\left(\mathrm{Y}_{2}\right)$.

The population in this study were all customers who had used Go-Jek transportation services in Denpasar city. This study involved 100 respondents as samples in a study that was determined 
based on non probability sampling techniques with a purposive sampling method (Sugiyono, 2017: 144). Respondents were determined based on several criteria, namely 1) live in Denpasar; 2) the education level of the respondent is at least high school / equivalent; 3) respondents have used the services of Go-Jek at least twice in the last three months.

Data was collected through survey methods by distributing questionnaires. The indicators of each variable in this study were measured based on the perceptions of respondents as users of the Go-Jek transportation service; using a 5-point Likert Scale, including: 1 = strongly disagree; 2 $=$ disagree; 3 = quite agree; 4 = agree; 5 = strongly agree.

Testing instruments in the form of validity and reliability tests was carried out on 30 respondents and it is important to do it as a condition to obtain results of the relevant research as primary data is obtained through questionnaires. Validity testing is carried out on all indicators with Pearson's Product Moment correlation technique provided that the correlation coefficient $(r)>0.3$ and significance $<0.05$. Reliability testing is carried out by all variables by calculating Cronbach's Alphareliability coefficient with Alpha Cronbach coefficient> 0.6 (Ghozali, 2016: 55; Sugiyono, 2017: 215).

The data analysis technique used in this study are 1) descriptive statistics are used to provide an overview of data in general; and 2) inferential statistics are used to answer the hypothesis. Inferential statistics used in this study are path analysis tests.

\section{Results and Discussion}

Research data obtained through questionnaires that have been distributed to 100 respondents. After the data is tabulated, an analysis of the data obtained using descriptive statistical analysis and inferential statistical analysis in the form of path analysis. Through these data, it is known that the survey was dominated by respondents with an age range of 17 to 21 years at 75 percent. The survey was also dominated by female respondents at 55 percent and the majority of respondents were students at 73 percent.

\section{The Result of Hypotesis' Testment}

Based on the hypothesis that has been proposed previously, there are two regression equations in this study. Regression equation 1 is used to answer hypotheses 1,2 and 3, while regression equation 2 is used to answer hypothesis 4 . The results of path analysis for the two regression equations are presented in Tabel 1.

Table 1. Result of the Path Analysis 


\begin{tabular}{|l|l|c|c|c|}
\hline Independent Variable & \multicolumn{1}{|c|}{ Dependent Variable } & $\begin{array}{c}\text { Path } \\
\text { Coefecient }\end{array}$ & $\rho$ value & Remark \\
\hline $\begin{array}{l}\text { Continuity marketing } \\
\left(\mathrm{X}_{1}\right)\end{array}$ & $\begin{array}{l}\text { Customers' } \\
\text { Satisfaction }\left(\mathrm{Y}_{1}\right)\end{array}$ & 0,350 & 0,000 & Accepted \\
\hline One to one marketing $\left(\mathrm{X}_{2}\right)$ & $\begin{array}{l}\text { Customers' } \\
\text { Satisfaction }\left(\mathrm{Y}_{1}\right)\end{array}$ & 0,373 & 0,000 & Accepted \\
\hline Partnering program $\left(\mathrm{X}_{3}\right)$ & $\begin{array}{l}\text { Customers' } \\
\text { Satisfaction }\left(\mathrm{Y}_{1}\right)\end{array}$ & 0,182 & 0,020 & Accepted \\
\hline $\begin{array}{l}\text { Customers' Satisfaction } \\
\left(\mathrm{Y}_{1}\right)\end{array}$ & $\begin{array}{l}\text { Customers' } \\
\text { Satisfaction }\left(\mathrm{Y}_{2}\right)\end{array}$ & 0,667 & 0,000 & Accepted \\
\hline
\end{tabular}

\section{$\mathrm{H}_{1}$ : Continuity marketing has a positive and significant effect on customers' satisfaction.}

The results of the path analysis on the effect of continuity marketing on customers' satisfaction indicate that the path coefficient value is 0.350 with $\rho$ value of 0.000 . Because the path coefficient $>0$ and $\rho$ value $\leq 0.05$, so H1 is accepted. This result means that continuity marketing has a positive and significant effect on customers' satisfaction.

\section{$\mathrm{H}_{2}$ : One to one marketing has a positive and significant effect on customer satisfaction.}

The results of path analysis on the effect of one to one marketing on customers' satisfaction indicate that the path coefficient value is 0.373 with $\rho$ value of 0.000 . Because the path coefficient $>0$ and $\rho$ value $\leq 0.05, \mathrm{H} 2$ is accepted. This result means that one to one marketing has a positive and significant effect on customers' satisfaction.

\section{$\mathrm{H}_{3} \quad$ : Partnering program has a positive and significant effect on customer satisfaction.}

The results of path analysis on the effect of partnering program on customers' satisfaction indicate that the path coefficient value is 0.182 with $\rho$ value of 0.020 . Because the path coefficient $>0$ and $\rho$ value $\leq 0.05$, so H3 is accepted. This result means that partnering programs have a positive and significant effect on customers' satisfaction.

$\mathrm{H}_{4} \quad$ : Customers' satisfaction has a positive and significant effect on customers' loyalty. 
The results of path analysis on the effect of customers' satisfaction on customers' loyalty indicate that the path coefficient value is 0.667 with $\rho$ value of 0.000 . Because the path coefficient $>0$ and $\rho$ value $\leq 0.05$, so $\mathrm{H} 4$ is accepted. This result means that customers' satisfaction has a positive and significant effect on customers' loyalty

\section{Research Discussion}

Based on the results of the calculation of validity and reliability, it can be concluded that each indicator is able to measure variables. This research model also fulfills the Goodness of Fi's requirements through the $\mathrm{F}$ test which means that overall this model is good at explaining the causal relationship between variables in the research model.

\section{The Effect of Continuity Marketing on the Satisfaction of Go-Jek Transportation Service Users in Denpasar city}

Table 1 shows that continuity marketing has a significant influence on the satisfaction of Go-Jek transportation service users. It is evidenced by the value of 0,000 which is less than 0.05 . The results also show the relationship between continuity marketing and customer satisfaction. With a path coefficient whose value is greater than 0 which is equal to 0.350 , it is known that the relationship between these variables is positive.

This result means that the better the application of the continuity marketing program to the GoJek transportation service company, the higher the level of customer satisfaction with the services offered by Go-Jek. This result is in line with the actual conditions that occur in the field. The results of the respondents 'assessment indicate that the respondents' assessment of the continuity marketing program is in a good category, resulting in a level of satisfaction in the good category. Respondents were satisfied with the implementation of the continuity marketing program such as reward points, discounts, and vouchers which given to Go-Jek's customers. The strategy of Go-Jek in implementing the continuity marketing program succeeded in increasing customer satisfaction with the services provided.

The Effect of One to One Marketing on the Satisfaction of Go-Jek Transportation Service Users in Denpasar city

Table 1 shows that one to one marketing has a significant influence on the satisfaction of Go-Jek transportation service users. It is evidenced by the value of 0,000 which is less than 0.05 . The results also show the relationship between one to one marketing and customer satisfaction. With a 
path coefficient whose value is greater than 0 which is equal to 0.373 , it is known that the relationship between these variables is positive. This result means that the better the application of one-to-one marketing programs to Go-Jek transportation services companies, the higher the level of customer satisfaction with the services offered by Go-Jek. This result is in line with the actual conditions that occur in the field. The results of the respondents 'assessment indicate that the respondents' assessment of the one to one marketing program is in a good category so that the satisfaction level is in the good category. Respondents were satisfied with the implementation of a one-to-one marketing program by Go-Jek by serving customers in friendly way, fast, goodskilled driving, and responsive in handling customers' complaints. Go-Jek's strategy in implementing a one-to-one marketing program succeeded in increasing customer satisfaction with the services provided.

\section{The Effect of Partnering Program on the Satisfaction of Go-Jek Transportation Service Users in Denpasar city}

Table 1 shows that partnering programs have a significant effect on the satisfaction of Go-Jek transportation service users. It is evidenced by the value of 0.020 which is less than 0.05 . The results also show the relationship between partnering programs and customer satisfaction. With a path coefficient whose value is greater than 0 which is equal to 0.182 , it is known that the relationship between these variables is positive. This result means that the better the implementation of partnering program in the Go-Jek transportation service company, the higher the level of customer satisfaction with the services offered by Go-Jek. This result is in line with the actual conditions that occur in the field. The results of the respondents 'assessment indicate that the respondents' assessment of the program partnering is in a good category so that the satisfaction level is in the good category. Respondents were satisfied with the implementation of partnering programs by Go-Jek, namely by partnering with other parties. Go-Jek's strategy in partnering the program succeeded in increasing customer satisfaction with the services provided.

\section{The Effect of Customers' Satisfaction on the Users' Loyalty in Using Go-Jek Transportation Services in Denpasar City}

Table 1 shows that customer satisfaction has a significant effect on the satisfaction of Go-Jek transportation service users. It is evidenced by the value of 0,000 which is less than 0.05 . The results also show the relationship between customer satisfaction and customer loyalty. With a path coefficient whose value is greater than 0 which is equal to 0.667 , it is known that the 
relationship between these variables is positive. This result means that the higher the level of customer satisfaction in the Go-Jek transportation service company, the higher the level of customer loyalty to the Go-Jek transportation service. This result is in line with the actual conditions that occur in the field. The results of the respondents' assessment indicate that the respondent's assessment of the level of customer satisfaction is in a good category resulting in a loyalty level in the good category. Respondents were satisfied with the implementation of partnering programs by Go-Jek, namely by partnering with other parties. Go-Jek's strategy in partnering the program succeeded in increasing customer satisfaction with the services provided. The Go-Jek strategy in increasing customer satisfaction by implementing continuity of marketing, one to one marketing, and good partnering programs can create customers' loyalty.

\section{Research Implications}

As stated in the results and discussion, in terms of this research theory can provide additional information about how the application of continuity marketing, one to one marketing, and partnering programs affect the satisfaction that can build customers' loyalty.

This research can also provide tangible benefits in creating customers' satisfaction and loyalty so that the results of this study can be a consideration for Go-Jek's transportation services going forward.

\section{Research Limitations}

There are some limitations encountered in this study, including: 1) The scope of the research is only carried out in the city of Denpasar, while the Go-Jek transportation service network is spread throughout almost Indonesia and even extends to the Southeast Asian region. So the results of this study cannot be generalized to customers in other cities; 2) The research subject is in the form of Go-Jek transportation services, so the results of this study cannot be generalized for other brands of transportation services; 3) This study still cannot reveal the overall factors that affect customers' loyalty to Go-Jek transportation service users in Denpasar City because there are still 24 percent of other factors which are not examined yet.

\section{Conclusion}

Based on the results and discussion of the influence of the CRM (Customer Relationship Management) on customers' satisfaction to build the customers' loyalty of Go-Jek transportation service users in Denpasar city, it can be concluded as follows: 1) continuity marketing has a 
positive and significant effect on customer satisfaction; 2) one to one marketing has a positive and significant effect on customer satisfaction; 3) partnering program has a positive and significant effect on customer satisfaction; 4) customers' satisfaction has a positive and significant effect on customer loyalty. Based on the results of the path analysis it can be seen that the one to one marketing variable is the most influential variable on customer satisfaction. Friendliness, speedy, skills, and responsiveness in handling customer complaints affect customers' satisfaction. In the second position, the variable continuity marketing is a variable that can affect customers' satisfaction such as the provision of reward points, discounts, and vouchers. In the last position, partnering program variables affect customer satisfaction. Partnerships with other parties can create customers' satisfaction. These three variables can create customer satisfaction in the GoJek transportation service company. More impact, this satisfaction shapes customer loyalty. Implementing the CRM can be a strategy for Go-Jek company so that customers feel satisfied with the services provided that will create customers' loyalty. The company can create customer loyalty to its services through increasing customers' satisfaction.

\section{References}

Ardiyhanto, D. 2011. Analisis Pengaruh Customer Relationship Management terhadap Loyalitas Pelanggan dalam Pembelian Sepeda Motor Yamaha pada PT Megatama Motor di Makasar. Universitas Hasanuddin, Makasar.

Ariff, Mohd Shoki M., Leong Ooi Yun, Norhayati Zakuan, dan Khalid Ismail. 2013. The Impacts of Service Quality and Customer Satisfaction on Customer Loyalty in Internet Banking. Social and Behavioral Sciences, 81, pp. 469-473.

Arokiasamy, Anantha Raj A. 2013. The Impact of Customer Satisfaction on Customer Loyalty and Intentions to Switch in The Banking Sector in Malaysia. The Journal of Commerce, 5(1), pp. 14-21.

Bhaskara, S.U.P., Silvya L. Mandey, dan Olivia Nelwan. 2014. Customer Relationship Management (CRM) dan Personal Selling Pengaruhnya Terhadap Kepuasan Konsumen Pada PT Virgo Ekspres Tours \& Travel Manado. Jurnal EMBA, 2(1), pp. 99-110.

Felix, R. 2016. Pengaruh Customer Relationship terhadap Loyalitas Pelanggan Tivoli Club House Sidoarjo dengan Kepuasan Pelanggan sebagai Variabel Perantara. Jurnal Hospitality dan Manajemen Jasa, 4(1), pp. 406- 421.

Ghozali, H. Imam. 2016. Aplikasi Analisis Multivariate dengan Program IMB SPSS 23. Edisi Ke Delapan. Semarang: Universitas Diponegoro

Griffin, Jill. 2005. Customer Loyalty: Menumbuhkan dan Mempertahankan Kesetiaan Pelanggan. Jakarta: Erlangga.

Indah, Purnama dan Devie. 2013. Analisa Pengaruh Customer Relationship Management Terhadap Keunggulan Bersaing dan Kinerja Perusahaan. Business Accounting Review, 1(2), pp. 50-60.

Iriandini A.P., Edy Y., dan Mawardi M.K. 2015. Pengaruh Customer Relationship Management (CRM) Terhadap Kepuasan Pelanggan dan Loyalitas Pelanggan (Survey pada Pelanggan PT. Gemilang Libra Logistics, Kota Surabaya). Jurnal Administrasi Bisnis, 23(2), pp. 1-8. 
Khodakarami Farnoosh dan Yolande E. C. 2014. Exploring The Role of Customer Relationship Management (CRM) Systems in Customer Knowledge Creation. Information and Management, 51, pp. 27-42.

Koduah, Ernest Yaw Tweneboah dan Augustine Yuty Duweh Farley. 2016. Relationship between Customer Satisfaction and Customer Loyalty in The Retail Banking Sector of Ghana. International Journal of Business and Management, 11(1), pp. 249-262.

Kotler, Philip dan Gary Armstrong. 2014. Principles of Marketing, 15 th Edition. New Jersey: Pearson Prentice Hall.

Kotler, Philip dan Kevin Lane Keller. 2012. Marketing Management, 14 ${ }^{\text {th }}$ Edition. Pearson Education, Inc.

Maidi dan Suwitho. 2014. Pengaruh Customer Relationship Management Terhadap Loyalitas Pelanggan PT. Moga Djaja Di Surabaya. Jurnal Ilmu dan Riset Manajemen, 3(8), pp. 1-16.

Mardikawati, W., dan Farida, N. 2013. Pengaruh Nilai Pelanggan dan Kualitas Layanan Terhadap Loyalitas Pelanggan, Melalui Kepuasan Pelanggan Pada Pelanggan Bus Efisiensi (Studi PO Efisiensi Jurusan Yogyakarta-Cilacap). Jurnal Administrasi Bisnis, 2(1), pp. 64-75.

Mohsan, Faizan, Muhammad M. N., M. Sarfaz Khan, Zeeshan Shaukat, dan Nauman Aslam. 2011. Impact of Customer Satisfication dan Intention to Switch: Evidence from Banking Sector of Pakistan. International Journal of Business and Social Science, 2(16), pp. 263-270.

Mokodongan, A. 2010. Analisis Penerapan Program Customer Relationship Management Hubungannya dengan Loyalitas Pelanggan (Studi Kasus di Swiss Bell Hotel Maleosan Manado). Inovasi, 7(4), pp. 240-271.

Oesman, Marty Yevis. 2010. Sukses Mengelola Marketing Mix, CRM, Customer Value, dan Customer Dependency (Kasus Pada Pemasaran Shopping Center). Bandung: Alfabeta.

Oktariana, Yuanira, Achmad Fauzi, dan Srikandi Kumadji. 2012. Faktor-Faktor Customer Relationship Management (Manajemen Hubungan Pelanggan) dalam Mewujudkan Kepuasan Anggota dan Dampaknya Terhadap Loyalitas Anggota (Survey Pada Anggota Koperasi Nusantara Cabang Malang di Kantor Pos Besar Malang). Jurnal Profit Volume, 6(2), pp. 149-161.

Paliouras, Konstantinos dan Kerstin V. Siakas. 2017. Social Customer Relationship Management: A Case Study. International Journal of Entrepreneurial Knowledge, 5, pp. 20-34.

Putra, Gempur Perdana Adha dan Ariyo Bramantory. 2013. Pelaksanaan Program Continuity Marketing dan One to One Marketing dalam Upaya Meningkatkan Loyalitas Pelanggan Royal Vanessa Hotel (Survei Pada Tamu Repeat Individu di Royal Vanessa Hotel Bengkulu). Tourism and Hospitality Essentials Journal,3(1), pp. 451-460.

Saputra, A., Jushermi dan Deny Danar Rahayu. 2015. Analisis Tingkat Kepuasan Atas Kualitas Pelayanan Jasa Pada Hotel Ratu Mayang Garden Pekanbaru. Jom Fekon, 2(1), pp. 1-15.

Setyaleksana, Bony Y., Suharyono, dan Edy Yulianto. 2017. Pengaruh Customer Relationship Management Terhadap Kepuasan dan Loyalitas Pelanggan. Jurnal Administrasi Bisnis, 46(1), pp. 45-51.

Sheth, Jagdish N., Atul Parvatiyar, dan Mona Sinha. 2015. The Conceptual Foundations of Relationship Marketing: Review and Synthesis. Journal of Economic Sociology, 16(2), pp. 119-149.

Sirait, Dodi Putra. 2018. Pengaruh Customer Relationship Management dan Kualitas Pelayanan Terhadap Kepuasan Pelanggan (The Effect of Relationship Management and Service Quality on Customer Satisfaction). Jurnal Digest Marketing, 3(1), pp. 79-85.

Sugiyono. 2017. Metode Penelitian Kuantitatif: Pendekatan Kuantitatif, Kualitatif, Kombinasi, dan $R \mathcal{E}$. Bandung: Alfabeta. 
Supar, D. A. Wina Ariyunita dan I G. A. K. Gede Suasana. 2017. Peran Kepuasan Pelanggan dalam Memediasi Pengaruh Customer Relationship Management Terhadap Loyalitas Pelanggan. E-Jurnal Manajemen Universitas Udayana, 6(3), pp. 1534-1563.

Sutrisno. 2015. Pengaruh Kualitas Layanan dan Customer Relationship Management Terhadap Kepuasan Pasien dan Loyalitas Pasien di Rumah Sakit Tingkat II Tentara Nasional Indonesia. Jurnal Ilmu Ekonomi dan Manajemen, 2(2), pp. 27-41.

Zakaria, Ibhrahim, Bahron Ab. Rahman, Abdul Kadir Othman, Noor Azlina Mohamed Yunus, Mohd Redhuan Dzulkipli, dan Mohd Akmal Faiz Osman. 2014. The Relationship between Loyalty Program, Customer Satisfaction and Customer Loyalty in Retail Industry: A Case Study. Procedia-Social Behavioral Science, 129, pp. 23-30. 